\title{
Methods for Identification of Substrates/Inhibitors of FCP/SCP Type Protein Ser/Thr Phosphatases
}

\author{
Masataka Mizunuma ${ }^{\dagger}$, Atsushi Kaneko ${ }^{\dagger}$, Shunta Imai, Kazuhiro Furukawa and \\ Yoshiro Chuman * \\ Department of Chemistry, Faculty of Science, Niigata University, 8050 2-no-cho, Ikarashi, Nishi-ku, \\ Niigata 950-2181, Japan; f19a501g@mail.cc.niigata-u.ac.jp (M.M.); f18j005b@mail.cc.niigata-u.ac.jp (A.K.); \\ f19a033c@mail.cc.niigata-u.ac.jp (S.I.); furukawa@chem.sc.niigata-u.ac.jp (K.F.) \\ * Correspondence: chuman@chem.sc.niigata-u.ac.jp; Tel./Fax: +81-25-262-6160 \\ + These authors contributed equally to this work.
}

Received: 29 October 2020; Accepted: 2 December 2020; Published: 4 December 2020

\begin{abstract}
Protein phosphorylation is the most widespread type of post-translational modification and is properly controlled by protein kinases and phosphatases. Regarding the phosphorylation of serine (Ser) and threonine (Thr) residues, relatively few protein Ser/Thr phosphatases control the specific dephosphorylation of numerous substrates, in contrast with Ser/Thr kinases. Recently, protein Ser/Thr phosphatases were reported to have rigid substrate recognition and exert various biological functions. Therefore, identification of targeted proteins by individual protein Ser/Thr phosphatases is crucial to clarify their own biological functions. However, to date, information on the development of methods for identification of the substrates of protein Ser/Thr phosphatases remains scarce. In turn, substrate-trapping mutants are powerful tools to search the individual substrates of protein tyrosine (Tyr) phosphatases. This review focuses on the development of novel methods for the identification of Ser/Thr phosphatases, especially small C-terminal domain phosphatase 1 (Scp1), using peptide-displayed phage library with $\mathrm{AlF}_{4}{ }^{-} / \mathrm{BeF}_{3}{ }^{-}$, and discusses the identification of putative inhibitors.
\end{abstract}

Keywords: protein Ser/Thr phosphatase; Scp1; peptide phage display; substrate identification

\section{Introduction}

Protein phosphorylation is strictly regulated by protein kinases and phosphatases, with more than $95 \%$ of phosphorylation affecting serine (Ser) and threonine (Thr) residues [1-3]. Protein dephosphorylation is mainly regulated by protein Ser/Thr phosphatases (PSPs) and protein tyrosine (Tyr) phosphatases (PTPs), and disorder of these enzymes contributes to several illnesses, including cancer and neurological disorders [4-8]. Therefore, it is important to identify substrates and inhibitors for individual protein Ser/Thr phosphatases to disclose their signaling pathways and disease-associated mechanisms.

PSPs comprise phosphoprotein phosphatases (PPP), metal-dependent protein phosphatases (PPM), and TFIIF-associating component of RNA polymerase II C-terminal domain (CTD) phosphatases/small CTD phosphatases (FCP/SCP) [2]. Most of PPP family members such as PP1, PP2A, and PP2B, act as holoenzymes by forming heterodimers or heterotrimers, in which highly conserved catalytic subunits interact with a variety of regulatory subunits to exert their unique functions in substrate preference, subcellular localization, and catalytic regulation [9-11]. Bimetallic centers of $\mathrm{Mn}^{2+}$ and $\mathrm{Fe}^{2+}$ are located in the active site of catalytic subunit in PPP type phosphatase PP1, and these two metal ions are coordinated by the highly conserved active center residues, such as histidines, asparatic acids, and asparagine, among the PPP family. These facts suggest that the catalytic mechanism is also conserved 
in these PPP type phosphatases. In contrast to the PPP family, PPM family members have additional domains and conserved motifs that may help substrate specificity instead of regulatory subunits in the PPP family. The PPM family contains $\mathrm{Mg}^{2+} / \mathrm{Mn}^{2+}$ ions in their active center, and work as monomeric enzymes with individual unique loops/inserts in each catalytic domain [12-14]. Although the sequences of PPMs differ from those of the PPP subfamily, their crystal structures reveal great structural similarity between them [15].

There are eight FCP/SCP phosphatases in humans that share the equivalent catalytic domain, with a DXDX(T/V) motif. $\mathrm{Mg}^{2+}$ is necessary for FCP/SCP phosphatase activity and the catalytic pocket makes a negatively charged surface, due to the conserved aspartic acid residues for $\mathrm{Mg}^{2+}$ coordination and catalysis [16]. This divalent metal-ion coordination site is in accord with the signature sequence observed in a family of metal-dependent phosphohydrolases and haloacid dehalogenases [17]. The small C-terminal domain (CTD) phosphatase 1 (Scp1), which is also known as Nuclear LIM interactor-interacting factor 3 (NLI-IF) or CTDSP1, belongs to the FCP/SCP type phosphatase and was originally identified as a protein Ser/Thr phosphatase targeting the CTD of the largest subunit of the RNA polymerase II (RNAPII), which includes tandem heptapeptide repeats of the sequence $\mathrm{Y}_{1} \mathrm{~S}_{2} \mathrm{P}_{3} \mathrm{~T}_{4} \mathrm{~S}_{5} \mathrm{P}_{6} \mathrm{~S}_{7}$. In particular, Scp1 preferentially dephosphorylates the modified Ser5 of CTD in RNA polymerase II (RNAPII) [2,18,19]. Recently, several proteins including Myc proto-oncogene protein (c-Myc), Twist related protein 1 (Twist1), small mothers against decapentaplegic protein (Smad), promyelocytic leukemia protein (PML), RAC-alpha serine/threonine-protein kinase (Akt), retinoblastoma protein ( $\mathrm{Rb})$, among other proteins, were also identified as Scp1 substrates, suggesting that this phosphatase plays important roles in the tumor suppression and BMB/TGF- $\beta$ signaling pathways [20-24]. In addition to the regulation of the function of RNAPII, Scp1 has shown the recognition preference for the PX(S/T)P sequence in the substrates, involving the CTD of RNAPII. However, several substrates do not include this sequence in their Scp1-targeted sites. Indeed, experimental data collected over the last decade about Scp1 and its substrates suggest that Scp1 dephosphorylates various substrates and is involved in a variety of processes [25-27]. To further understand the biological functions of Scp1, novel approaches to explore its substrate motifs or sequences must be developed.

Among its many functions, Scp1 can support tumor suppression. However, recent studies have shown that Scp1 is expressed in neuroglioma cells and that its downregulation inhibits neuroglioma cell migration $[28,29]$. These data suggest that Scp1 may represent a potential drug target and Scp1-specific inhibitors may represent valuable therapeutics for preventing the spreading of particular tumors. To date, some studies have reported specific inhibitors for FCP/SCP-type PSPs, including for Scp1 [30,31]. It is reported that rabeprazole, which is a drug for gastroesophageal reflux disease, can function as a specific inhibitor for Scp phosphatases including Scp1, but it did not show the inhibitory activity against other FCP/SCP type phosphatase, Fcp1 and Dullard, or bacteriophage $\lambda$ Ser/Thr phosphatases [30,32]. Recently, a structure-based drug design approach has been one of the successful strategies to explore molecular targets. Park and colleagues discovered both competitive and allosteric inhibitors for Scp1 by two-track virtual screening procedure [33]. Furthermore, some modifications of the inhibitors to improve the biochemical potency were advocated on the basis of the binding modes with docking simulations. Thus far, several chemical inhibitors for Scp1 have been reported, and these compounds can be used for therapeutic purposes or as tools to further explore Scp1 biological roles. Additionally, PP1, which belongs to the PPP subfamily, is controlled by several endogenous inhibitory proteins, including inhibitor-1 (I-1), inhibitor-2 (I-2), KEPI, and CPI-17 [34-37]. This further suggests that the identification of small compound inhibitors and of endogenous inhibitors derived from proteins and peptides may help to elucidate the biological functions of PSPs, including Scp1.

In order to isolate the endogenous substrates/inhibitors bound to the active site of the interested enzyme, it is necessary to realize the catalytic mechanisms. Substrate-trapping mutants for protein Tyr phosphatase have been designed based on the mutation of the cysteine (Cys) residue in the active site, which makes a covalent intermediate between the substrate and the enzyme [38-40]. No such substrate-trapping strategy has been identified in the PSPs, since they hydrolyze phosphate esters in a 
single step without covalent intermediate [41]. Nevertheless, our group and other researchers have recently reported novel methods to identify substrates/inhibitors derived from endogenous proteins or peptide motifs for PSPs [42-44]. One strategy uses the hypoactive fusions of PP1 and the regulatory subunits for PPP-type PSPs, and other is the phosphorylation mimic phage display (PMPD) method for FCP/SCP-type PSPs. This review introduces the classical strategies that can be used to identify the substrates of Scp1, and also explores novel methods for substrates/inhibitors identification for the PSPs.

\section{Substrate Identification Methods Using Expression Screening Strategy, Functional Analysis, and Proteomic Screening}

Recent investigations on Scp1 revealed that it dephosphorylates various substrates associated with several signaling pathways, including cell cycle regulation, neuronal gene silencing, and osteoblast differentiation. Most of these substrates were identified using an expression screening strategy for protein phosphatases (Table 1).

Table 1. Scp1 substrates and their dephosphorylation sites.

\begin{tabular}{|c|c|c|c|c|}
\hline Proteins & Target Sites & Sequences & Methods & References \\
\hline RNAPII CTD & pS5 & YSPTpSPS & Functional analyses & [2] \\
\hline c-Myc & pS62 & LLPTPPLpSPSRRSGL & Expression screening & [20] \\
\hline Twist1 & pS68 & GGGDEPGpSPAQGKRG & Expression screening & [21] \\
\hline PML & pS518 & PSTSKAVpSPPHLDGP & Expression screening & [22] \\
\hline $\mathrm{RB}$ & $\begin{array}{l}\text { pS807* } \\
\text { pS811* }\end{array}$ & $\begin{array}{l}\text { NIYIpSPLKS } \\
\text { SPLKpSPYKI }\end{array}$ & Functional analyses & [24] \\
\hline Akt & $\begin{array}{l}\text { pS473 } \\
\text { pT308 } \\
\text { pS245* }\end{array}$ & $\begin{array}{l}\text { RPHFPQFpSYSASGTA } \\
\text { KDGATMKpTFCGTPEY } \\
\text { NQSMDTGpSPAELSPT }\end{array}$ & Functional analyses & [25] \\
\hline Smad2 & $\begin{array}{l}\text { pS250* } \\
\text { pS255* }\end{array}$ & $\begin{array}{l}\text { TGSPAELPSPTTLSPV } \\
\text { ELSPTTLPSPVNHSLD }\end{array}$ & Expression screening & [26] \\
\hline Snail1 & $\begin{array}{l}\text { pS96* } \\
\text { pS100* } \\
\text { pS107* } \\
\text { pS111* } \\
\text { pS115* } \\
\text { pS119* }\end{array}$ & $\begin{array}{l}\text { TSLSDEDpSGKGSQPP } \\
\text { DEDSGKGpSQPPSPPS } \\
\text { SQPPSPPpSPAPSSFS } \\
\text { SPPSPAPpSSFSSTSV } \\
\text { PAPSSFSpSTSVSSLE } \\
\text { SFSSTSVpSSLEAEAY }\end{array}$ & Expression screening & [27] \\
\hline REST & $\begin{array}{l}\text { pS861 } \\
\text { pS864 }\end{array}$ & $\begin{array}{l}\text { SVSTEDLPSPPSPPLP } \\
\text { TEDLSPPpSPPLPKEN }\end{array}$ & Functional analyses & [45] \\
\hline CdcA3 & $\begin{array}{l}\text { pS29 } \\
\text { pS68 }\end{array}$ & $\begin{array}{l}\text { ADPRpSPSAG } \\
\text { SDPRpSPTLG }\end{array}$ & Proteomic screening & [46] \\
\hline UTF1 & $\begin{array}{l}\text { pS18 } \\
\text { pS245 }\end{array}$ & $\begin{array}{c}\text { PAPPpSPASP } \\
\text { VRGPGpSPPPPP }\end{array}$ & Proteomic screening & [46] \\
\hline
\end{tabular}

CTD: C-terminal domain; pS: phosphorylated serine; pT: phosphorylated threonine; PML: promyelocytic leukemia protein; RB: retinoblastoma protein; Akt: RAC-alpha serine/threonine-protein kinase; REST: RE1-silencing transcription factor; CdcA3: cell division cycle-associated protein; UTF1: undifferentiated embryonic cell transcription factor 1 . Asterisk $\left({ }^{*}\right)$ indicates the Scp1-targeting sites that are not identified by the individual site-specific mutation analyses or anti-phosphospecific antibodies.

c-Myc and Twist1 were identified as targeted proteins of Scp1 by analyzing their phosphorylation levels in the presence of 40 and 39 protein phosphatases, respectively, in HEK293T cells [20,21]. Phosphorylation of c-Myc at Ser62 affects the protein stability in cancer cells; therefore, Scp1 may act as a tumor suppressor through the dephosphorylation of c-Myc Ser62 in liver cancers [18]. Scp1 was also reported to hold tumor suppressor functions through the dephosphorylation of Ser68 of Twist1, which is a transcription factor and promotes epithelial-to-mesenchymal transition (EMT), invasion, and migration of cancer cells [21]. PML and Smad were also reported to be targets of Scp1, but also of its isoforms Scp2 and 3, by co-expression analyses of these proteins in HEK293 cells [22,26,47]. Smad proteins function as important signal transducers in the TGF- $\beta$ /bone morphogenetic protein (BMP) signaling pathway. RNA interference-mediated knockdown of Scp1 further revealed that Scp1 
dephosphorylates Smad proteins, resulting in the attenuation of BMP signaling. Wu et al. reported that Snail is also a target protein of Scp1 by analyzing the stabilization of Snail protein upon co-expression with 11 protein phosphatases. In this study, Scp1 dephosphorylated GSK-3 $\beta$ motifs on Snail, regulating the stability and localization of Snail in cells. The stabilization of Snail by Scp1 enhanced the activity of the protein, which in turn inhibited E-cadherin and increased cell migration [27]. Thus, a variety of targeted Scp1 proteins have been identified using the expression screening strategy.

Several proteins were also identified as Scp1-targeted proteins through functional analyses. RE1-silencing transcription factor (REST) was originally reported to be regulated by Scp1 through the parallel expression pattern of REST and Scps, including Scp1, in non-neuronal tissues but not in neural cells [48]. Ser861 residue of REST was reported to be directly dephosphorylated by Scp1, resulting in its activation and the regulation of neural gene silencing through the expression of REST-targeted genes $[45,49]$. Moreover, Peng et al. reported that Scp1 localizes not only in the nucleus but also in the plasma membrane through palmitoylation, and regulates angiogenesis and tumorigenesis by the dephosphorylation of Akt at Ser473 [25]. More recently, Rb was also reported as a Scp1-targeted protein; thereby, the tumor-suppressive activity of Scp 1 can achieved by increasing the proportion of the active form of $\mathrm{Rb}$ protein dephosphorylated at Ser807/811, Ser780, and Ser795 [24].

Kim and colleagues reported that Scp1 dephosphorylates cell division cycle-associated protein (CdcA3, also designated as TOME1), which was identified as a binding partner and substrate of Scp1 by proteomic screening of co-immunoprecipitation with Scp1 expressed in NIH/3T3 and HEK293T cells [46]. CdcA3 is correlated with the ubiquitination and degradation of Wee1 kinase, suggesting that Scp1 might be involved in cell cycle regulation through the dephosphorylation of CdcA3 [50]. Thus, in the last decade, several Scp1-targeted proteins were identified mainly by expression screening and functional strategy (Table 1).

\section{Substrate Identification Method by Fusion Proteins of Hypoactive PP1 Mutant the Regulatory Interactors of Protein Phosphatase One (RIPPO)}

Substrate-trapping mutants against enzymes of interest are powerful tools to identify their individual substrates and clarify their biological functions. Several substrate trapping mutants were reported for the PTP family, whereas for the PSP family have not [38-40]. This is due to differences in the catalytic mechanism of their phosphates, since PTPs have a cysteine residue in a catalytic site that makes a covalent intermediate with the substrate in a first step, and then hydrolyzes the substrate in a second step. Therefore, mutants of the active-site cysteine in PTPs play a role in substrate trapping. In contrast, PSPs catalyze the hydrolysis of their substrates without covalent intermediate. These facts justify the development of methods for the identification of substrates for PSPs.

Recently, Wu and colleagues reported the identification strategy of substrates for protein Ser/Thr phosphatase PP1 by an easy-to-use tool. This novel approach used a fusion protein resulting from the combination of a PP1 mutant of aspartic acid residue at the catalytic site with the RIPPOs [42]. In this study, they focused on the hetero-oligomerization of the catalytic subunit of PPP-type PSPs with non-catalytic subunits that have low binding sites for substrates and contribute to substrate recognition. Fusions of a hypoactive point mutant of PP1 at the catalytic site and one of the four RIPPOs, either NIPP1, RepoMan, PNUTS, or MYPT1, were expressed in the cells to identify their individual substrates by co-immunoprecipitation. These experiments revealed that the interaction of inactive PP1 and RIPPOs with their substrates remains intact during the treatment of immunoprecipitation, allowing the identification of their individual substrates by using immunoblotting or mass spectrometry analysis. Thus, the fusion proteins of inactive catalytic subunit and RIPPOs may represent powerful tools for substrate-trapping methods for PPP-type PSPs.

\section{Phosphorylation Mimic Phage Display (PMPD) Method for Scp1}

So far, eight putative CTD phosphatases, including Scp1, have been identified in the human genome [16]. Results from co-crystallizations of enzymes with metal fluorides have revealed that 
$\mathrm{AlF}_{4}{ }^{-}$and $\mathrm{BeF}_{3}^{-}$mimic either a phosphoryl or a phosphate group in several enzymes, including kinases, phosphatases, mutases, phosphohydrolases, GTPases, and ATPases [51,52]. Recently, several crystal structures of $\mathrm{FCP} / \mathrm{SCP}$ phosphatase have been resolved with $\mathrm{AlF}_{4}{ }^{-} / \mathrm{AlF}_{3}$ or $\mathrm{BeF}_{3}{ }^{-}[16,51,53,54]$. These crystal structures clarified that both $\mathrm{AlF}_{4}{ }^{-} / \mathrm{AlF}_{3}$ and $\mathrm{BeF}_{3}{ }^{-}$make a complex with $\mathrm{Mg}^{2+}$ in the catalytic center in $\mathrm{FCP} / \mathrm{SCP}$ phosphatases, and that the $\mathrm{Mg}^{2+}-\mathrm{AlF}_{4}{ }^{-} / \mathrm{AlF}_{3}$ mimics the transition state of the hydrolysis step, whereas the $\mathrm{Mg}^{2+}-\mathrm{BeF}_{3}{ }^{-}$mimics the phosphoaspartate intermediate. Thus, we recently developed a novel method, termed the phosphorylation mimic phage display (PMPD) method, to identify substrates/inhibitors of Scp1 using phage-displayed peptide library with $\mathrm{AlF}_{4}{ }^{-}$or $\mathrm{BeF}_{3}^{-}$(Figure 1).

\section{Phosphorylation Mimic Phage Display Method (PMPD Method)}

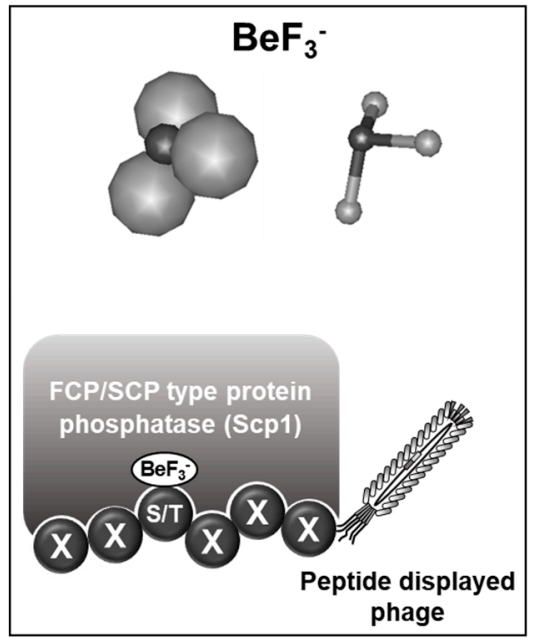

Phosphoaspartate intermediate mimic

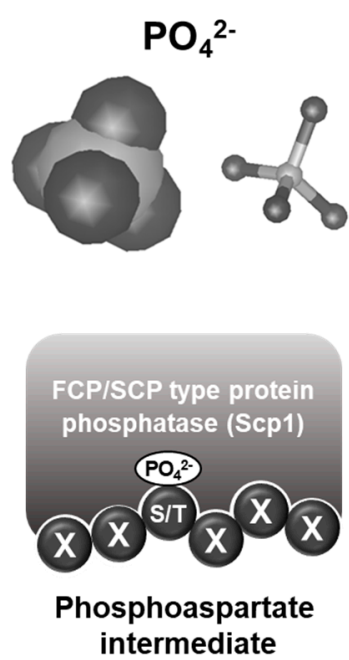

intermediate

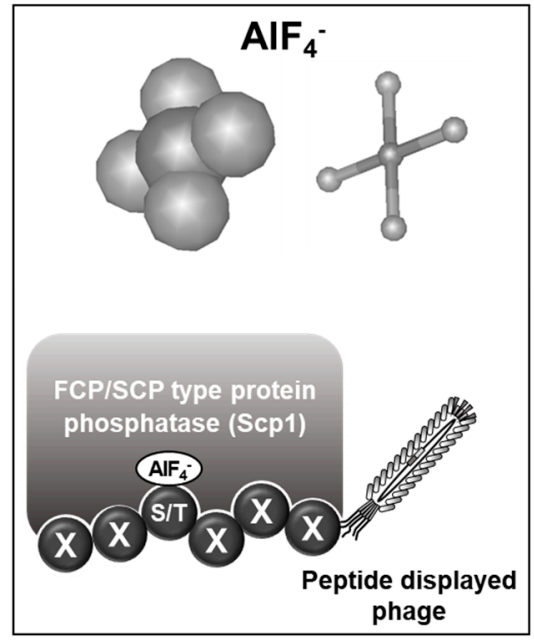

Transition state mimic

Figure 1. Phosphorylation mimic phage display (PMPD) method to identify the specific peptides derived from substrates/inhibitors for TFIIF-associating component of RNA polymerase II C-terminal domain (CTD) phosphatases/small CTD phosphatases (FCP/SCP type protein Ser/Thr phosphatases).

\subsection{Scp1 Substrate Identification by PMPD Method with $\mathrm{AlF}_{4}^{-}$}

Crystal structures of $\mathrm{FCP} / \mathrm{SCP}$ phosphatase were solved with $\mathrm{AlF}_{4}{ }^{-}$, in which the $\mathrm{AlF}_{4}{ }^{-}$complex acts as a phosphate analogue, inducing the proposed pentacoordinate phosphorane transition state of the hydrolysis reaction [51,53]. Enzymes recognize their substrates with high affinity, as an antibody to their haptens, which have been exhibited by X-ray crystallography [55,56]. In fact, we demonstrated that the phosphatase activities of FCP/SCP family phosphatases such as Fcp1 and Scp1 were strongly inhibited by $\mathrm{AlF}_{4}{ }^{-}$. This feature supports our contention that the transition state of the Scp1- $\mathrm{Mg}^{2+}-\mathrm{AlF}_{4}{ }^{-}$complex may interact with unphosphorylated peptides with high affinity to function as phosphorylated-substrate mimics. We have focused on the role of $\mathrm{AlF}_{4}{ }^{-}$as a phosphate mimic and developed the PMPD method using $\mathrm{AlF}_{4}{ }^{-}$and the phage-displayed peptide library to potentially identify substrate candidate peptides for Scp1 [43].

In this study, peptide-displayed phage libraries were incubated in a Scp1-immobilized enzyme-linked immunosorbent assay (ELISA) plate with addition of $\mathrm{AlF}_{4}{ }^{-}$. After washing, phages that bound to Scp1 in $\mathrm{AlF}_{4}{ }^{-}$-dependent manner were eluted and subjected to sequence and binding analyses. Sequence analyses revealed that several peptides, including AlM12-1 and Dep-3, were identified as convergent sequences with several frequencies (Table 2). 
Table 2. Peptides identified by PMPD methods for substrates/inhibitors of Scp1.

\begin{tabular}{cc}
\hline Name & Sequence \\
\hline$<$ PMPD method with $\mathrm{AlF}_{4}^{-}[43]>$ & C R G A T P M S C \\
Dep-3 & D Y H D P L P T L R K \\
AlM12-1 & \\
$<$ PMPD method with $\mathrm{BeF}_{3}^{-}[44]>$ & T A K Y L P M R P G P L \\
BeM12-1 & DYH D P S L T L R K \\
AlM12-1
\end{tabular}

Moreover, binding analysis showed that each phage displayed these peptides bound to Scp1 in $\mathrm{AlF}_{4}{ }^{-}$-dependent manner, showing that endogenous proteins containing phosphorylated sequence derived from these phages may be targeted by Scp1. In particular, the identified Dep-3 peptide includes a Thr-Pro-Met-Ser sequence that shows the similarity to the $\mathrm{Ser}_{2}-\mathrm{Pro}_{3}-\mathrm{Thr}_{4}-\mathrm{Ser}_{5}$ sequence of RNAPII CTD, known as endogenous Scp1-substrate. Crystallographic analysis of Scp1 with a phosphorylated peptide revealed that the $\mathrm{Ser}_{2}-\mathrm{Pro}_{3}-\mathrm{Thr}_{4}-\mathrm{Ser}_{5}$ derived from RNAPII CTD sequence binds to the groove in the active site of Scp1, resulting in the dephosphorylation of Ser5 residue [16]. These observations suggest that our PMPD method with $\mathrm{AlF}_{4}{ }^{-}$could successfully isolate the substrate candidates of FCP/SCP phosphatases, such as Scp1. Contrasting with Dep-3, AlM12-1 did not show any homology to CTD sequence; however, further analysis using protein database demonstrated that the Pro-Ser-Leu-Pro sequence in AlM12-1 was similar with the sequence of Pro-Ser-Ala-Pro in Hrs, which is zinc finger protein and involved in intracellular signal transduction [57]. Bouanmr and colleagues showed that the sequence of Pro-Ser-Xxx-Pro in Hrs is a well-defined motif that associates with the protein-protein interactions, also detected in other protein [58]. These observations support the intention that the phosphorylated Pro-Ser-Leu-Pro sequence derived from AlM12-1 peptide may be recognized by Scp1. Furthermore, AlM12-1 shows that the similar sequence is also observed in spectrin and TRIM46, whereas phosphorylation of the similar sequence in these proteins has not been reported $[59,60]$. However, both of these proteins play significant roles in neurological pathways, and disorders of these proteins are expected to cause neurological diseases, suggesting that these proteins may be targeted and controlled by Scp1 through the enzymatic activity against these proteins. In addition, we have confirmed that $\mathrm{AlF}_{4}{ }^{-}$inhibited not only Scp 1 but also other FCP/SCP type phosphatase Fcp1. These facts strongly suggest that the PMPD method using $\mathrm{AlF}_{4}{ }^{-}$may be applicable for screening of the substrate-peptide motifs for FCP/SCP type phosphatases. Further analyses using other FCP/SCP type phosphatases will support the usefulness of PMPD methods for the research of substrate screening.

\subsection{Scp1 Substrates/Inhibitors Identification by PMPD Method with $\mathrm{BeF}_{3}{ }_{-}^{-}$}

$\mathrm{BeF}_{3}{ }^{-}$has been known to mimic a phosphate group and form a stable tetrahedral adduct with catalytic aspartic acids, mimicking a phosphoaspartate intermediate in a family of metal-dependent phosphohydrolases and haloacid dehalogenases [51,52,61]. Crystallographic analysis of Scp1 with $\mathrm{BeF}_{3}{ }^{-}$also clarified that $\mathrm{BeF}_{3}{ }^{-}$plays as a phosphate mimic and depresses the enzymatic activity [53]. Kamenski and colleagues also showed that the enzymatic activity of both Scp1 and Fcp1 were inhibited by $\mathrm{BeF}_{3}{ }^{-}$, although the inhibition by $\mathrm{AlF}_{4}{ }^{-}$was less serious [51]. These observations suggest that $\mathrm{BeF}_{3}{ }^{-}$may show stronger binding to Scp1 than $\mathrm{AlF}_{4}{ }^{-}$, and that the identification of peptides by PMPD method using $\mathrm{BeF}_{3}{ }^{-}$may help to isolate new substrate/inhibitor candidates for Scp1, giving new insights on the biological functions for Scp1. In PMPD method using $\mathrm{BeF}_{3}{ }^{-}$, several sequences, including BeM12-1 and AlM12-1, were determined as Scp1-binding peptides in a $\mathrm{BeF}_{3}{ }^{-}$-dependent manner (Table 2). Interestingly, phosphatase analysis using synthetic phosphorylated peptides derived from BeM12-1 and AlM12-1 revealed that phosphorylated AlM12-1 at Ser6 acted as a substrate for Scp1, whereas phosphorylated BeM12-1 at Thr1 was as an inhibitor for Scp1. These observations indicate that the PMPD method using $\mathrm{BeF}_{3}{ }^{-}$may be useful to identify not only substrates but also inhibitors of the 
FCP/SCP type phosphatase. Furthermore, we confirmed that phosphorylated BeM12-1(1pS) peptide, in which Ser1 was substituted for Thr1 in BeM12-1(1pT) peptide, was dephosphorylated by Scp1 (data not shown). These data indicated that the Thr1 residue but not Ser1 is critical for the inhibitory function of phosphorylated BeM12-1(1pT) peptide against Scp1. These facts give us new insight on the different effects between Ser and Thr residues to evaluate the peptide-derived inhibitors/substrates for protein Ser/Thr phosphatases.

\subsection{Methods}

\subsubsection{Isolation of Putative Peptides Derived from Substrates/Inhibitors of Scp1 by PMPD Methods}

Recombinant Scp1 dissolved in maleate buffer (20 mM Na-maleate (Fuji-film Wako, Tokyo, Japan) pH 5.5, $150 \mathrm{mM} \mathrm{NaCl}$ (Fuji-film Wako, Tokyo, Japan)) was immobilized on ELISA plate overnight at $4{ }^{\circ} \mathrm{C}$. After the blocking treatment with blocking buffer including BSA, the wells were washed using washing buffer (maleate buffer with $5 \mathrm{mM} \mathrm{MgCl}_{2}$ (Nacalai Tesque, Kyoto, Japan), $0.05 \mathrm{mM} \mathrm{AlCl}_{3}$ (Fuji-film Wako, Tokyo, Japan) or BeSO 4 (Fuji-film Wako, Tokyo, Japan), and 1 mM NaF (Nacalai Tesque, Kyoto, Japan)). $10^{10}$ phages (New England BioLabs, Beverly, MA, USA) was added to Scp1-immobilized plate and incubated at room temperature. After washing with washing buffer including $\mathrm{AlF}_{4}{ }^{-} \mathrm{Or} \mathrm{BeF}_{3}^{-}$, Scp1-binding phages in $\mathrm{AlF}_{4}{ }^{-}$or $\mathrm{BeF}_{3}{ }^{-}$-dependent manner were recovered by elution with washing buffer without $\mathrm{AlF}_{4}{ }^{-} / \mathrm{BeF}_{3}{ }^{-}$. After amplification of the eluted phages, the phages were subjected to the next panning. After the 3rd or 4th round of panning, the recovered phages were counted and their sequences were analyzed (Figure 2).

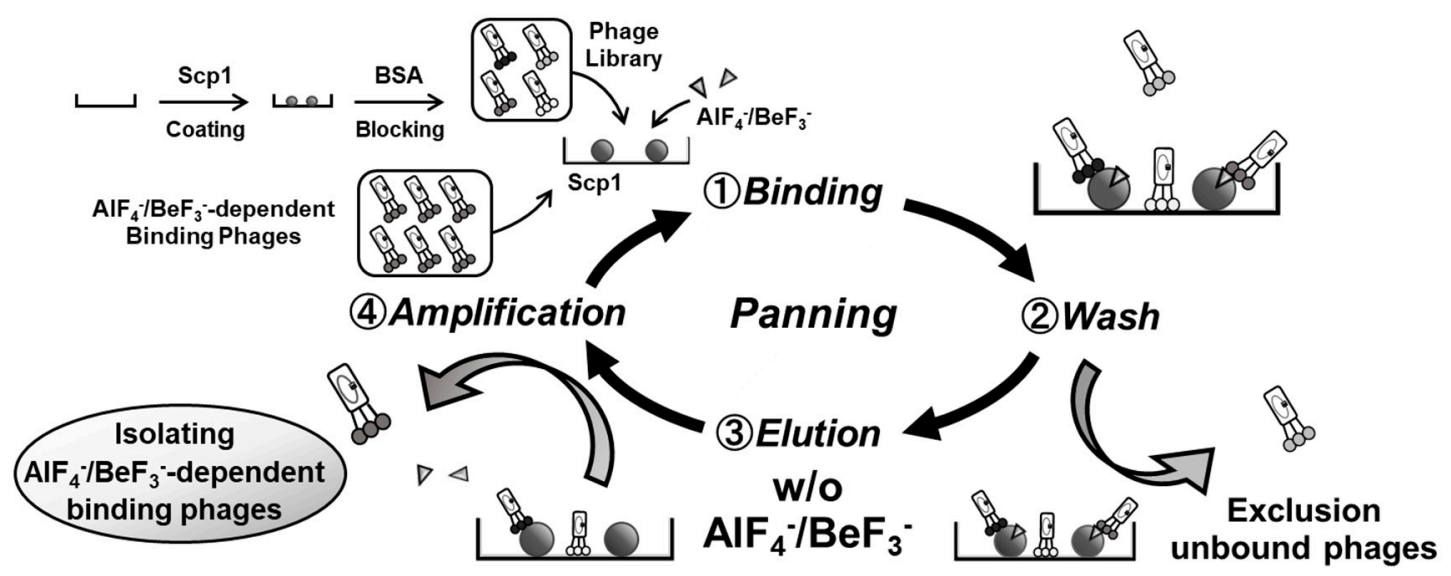

Figure 2. Scheme of screening of peptidyl substrates/inhibitors of Scp1 by PMPD methods.

\subsubsection{Binding Analysis of Recovered Phages against Scp1 with $\mathrm{AlF}_{4}{ }^{-} / \mathrm{BeF}_{3}{ }^{-}$in ELISA}

Recombinant Scp1 was coated to ELISA plate overnight at $4{ }^{\circ} \mathrm{C}$ in washing buffer including $\mathrm{AlF}_{4}{ }^{-} / \mathrm{BeF}_{3}{ }^{-}$. After that, blocking buffer was added and incubated for $3 \mathrm{~h}$ at $4{ }^{\circ} \mathrm{C}$. Then, $10^{8 \sim 10}$ phages in washing buffer were added to each well and incubated for $1 \mathrm{~h}$ at room temperature. After wells were washed more than $20 \times$ with washing buffer, anti-M13 phage antibody was incubated at room temperature. Then, anti-rabbit antibody-conjugated HRP was added and incubated at room temperature. After washing, Scp1-binding phages were detected with ABTS (2,2'-Azinobis(3-ethylbenzothiazoline-6-sulfonic acid)-diammonium salt)/ $\mathrm{H}_{2} \mathrm{O}_{2}$ solution (Sigma-Aldrich, Saint Louis, MO, USA), and quantified by measuring the absorbance at $405 \mathrm{~nm}[43,44]$.

4.3.3. In Vitro Phosphatase Assay for Phosphorylated Peptides Derived from Isolated Clones by PMPD Methods

Scp1 phosphatase activity to phosphorylated peptides derived from identified sequence by PMPD methods were measured in reaction buffer $(20 \mathrm{mM}$ Na-maleate pH 5.5, $10 \mathrm{mM} \mathrm{MgCl}$ ) with 
$10 \mathrm{nM}$ of Scp 1 for $10 \mathrm{~min}$ at $37^{\circ} \mathrm{C}$. Phosphatase reactions were quenched by addition of malachite green reagent (Enzo Life Science, Plymouth, PA, USA). The release of free inorganic phosphate from the phosphorylated peptide was measured with the absorbance at $620 \mathrm{~nm}$. To examine the inhibitory activity of phosphorylated peptide identified by PMPD method against Scp1, pNPP ( $p$-Nitrophenylphosphate) and phosphorylated peptide of CTD at Ser5 were used as substrate. Inhibitory activity of phosphorylated peptides using pNPP as substrate was measured with the absorbance at $410 \mathrm{~nm}$ after the reaction with $10 \mathrm{nM} \mathrm{Scp} 1$ for $7 \mathrm{~min}$ at $37^{\circ} \mathrm{C}$. In the case of inhibitory activity analysis using peptide substrates, $10 \mathrm{nM}$ of Scp1 was incubated with phosphorylated peptide identified by PMPD methods in the reaction buffer for $10 \mathrm{~min}$, then the released free inorganic phosphate was quantified with the absorbance at $620 \mathrm{~nm}[43,44]$.

\section{Conclusions}

Phosphorylation sites on Ser and Thr residues are known to occupy more than $95 \%$ of phosphorylated amino acids in humans. PSPs dephosphorylate these residues and play important roles in numerous signaling pathways, such as cell proliferation, cell differentiation, and cell development, through the regulation of the catalytic activity and subcellular localization of the targeted proteins. PSPs dephosphorylate a number of endogenous substrates/inhibitors, thus exerting their various biological functions, but their binding to targets is strictly restricted. In this review, we summarize novel screening methods, such as the PMPD, to identify substrates/inhibitors of the FCP/SCP-type Scp1, in addition to other classical strategies including the substrate-trapping method by the fusion proteins of inactive catalytic subunits of PP1 and RIPPOs. These methods are powerful tools to clarify the complicated biological functions of PSPs, as well as to develop novel therapeutic drugs for treated human illnesses, including cancer.

Author Contributions: Conceptualization, M.M., A.K. and Y.C.; methodology, M.M., A.K. and Y.C.; validation, M.M., A.K. and Y.C.; formal analysis, A.K.; investigation, M.M., A.K., and S.I.; resources, S.I. and Y.C.; data curation, M.M., A.K. and S.I.; writing — original draft preparation, M.M., A.K.; writing-review and editing, M.M., A.K., S.I., K.F. and Y.C.; visualization, M.M., A.K., S.I. and Y.C.; supervision, K.F., Y.C.; project administration, Y.C.; funding acquisition, A.K., Y.C. All authors have read and agreed to the published version of the manuscript.

Funding: This work was supported in part by a Grant-in-Aid for Scientific Research (C) (No. 15K05560), (B) (No. 19H03512), and Grant-in-Aid for Challenging Research (Exploratory) (No. 20K21541) (to Y.C.) from the Japanese Society for the Promotion of Sciences, Research Fellowships for Young Scientists from JSPS (No. 18J20422 to A.K.) and U-go grant from Niigata University (to Y.C.).

Conflicts of Interest: The authors declare no conflict of interest.

\section{References}

1. Olsen, J.V.; Blagoev, B.; Gnad, F.; Macek, B.; Kumar, C.; Mortensen, P.; Mann, M. Global, in vivo, and site-specific phosphorylation dynamics in signaling networks. Cell 2006, 127, 635-648. [CrossRef] [PubMed]

2. Shi, Y. Serine/threonine phosphatases: Mechanism through structure. Cell 2009, 139, 468-484. [CrossRef] [PubMed]

3. Sharma, K.; D’Souza, R.C.J.; Tyanova, S.; Schaab, C.; Wiśniewski, J.R.; Cox, J.; Mann, M. Ultradeep human phosphoproteome reveals a distinct regulatory nature of Tyr and Ser/Thr-based signaling. Cell Rep. 2014, 8, 1583-1594. [CrossRef] [PubMed]

4. Mazhar, S.; Taylor, S.E.; Sangodkar, J.; Narla, G. Targeting PP2A in cancer: Combination therapies. Biochim. Biophys. Acta Mol. Cell Res. 2019, 1866, 51-63. [CrossRef] [PubMed]

5. Clark, A.R.; Ohlmeyer, M. Protein phosphatase $2 \mathrm{~A}$ as a therapeutic target in inflammation and neurodegeneration. Pharmacol. Ther. 2019, 201, 181-201. [CrossRef]

6. Varon, R.; Gooding, R.; Steglich, C.; Marns, L.; Tang, H.; Angelicheva, D.; Yong, K.K.; Ambrugger, P.; Reinhold, A.; Morar, B.; et al. Partial deficiency of the C-terminal-domain phosphatase of RNA polymerase II is associated with congenital cataracts facial dysmorphism neuropathy syndrome. Nat. Genet. 2003, 35, 185-189. [CrossRef] [PubMed] 
7. Chuman, Y.; Kurihashi, W.; Mizukami, Y.; Nashimoto, T.; Yagi, H.; Sakaguchi, K. PPM1D430, a novel alternative splicing variant of the human PPM1D, can dephosphorylate p53 and exhibits specific tissue expression. J. Biochem. 2009, 145, 1-12. [CrossRef]

8. Hertog, J. Regulation of protein phosphatases in disease and behaviour. EMBO Rep. 2003, 4, 1027-1032. [CrossRef]

9. Heroes, E.; Lesage, B.; Görnemann, J.; Beullens, M.; Meervelt, L.V.; Bollen, M. The PP1 binding code: A molecular-lego strategy that governs specificity. FEBS J. 2013, 280, 584-595. [CrossRef]

10. Virshup, D.M.; Shenolikar, S. From promiscuity to precision: Protein phosphatases get a makeover. Mol. Cell 2009, 33, 537-545. [CrossRef]

11. Yadav, L.; Tamene, F.; Göös, H.; Drogen, A.; Katainen, R.; Aebersold, R.; Gstaiger, M.; Varjosalo, M. Systematic Analysis of Human Protein Phosphatase Interactions and Dynamics. Cell Syst. 2017, 4, 430-444.e5. [CrossRef] [PubMed]

12. Kamada, R.; Kudoh, F.; Ito, S.; Tani, I.; Janairo, J.I.B.; Omichinski, J.G.; Sakaguchi, K. Metal-dependent Ser/Thr protein phosphatase PPM family: Evolution, structures, diseases and inhibitors. Pharmacol. Ther. 2020, 215, 107622. [CrossRef] [PubMed]

13. Chuman, Y.; Yagi, H.; Fukuda, T.; Nomura, T.; Matsukizono, M.; Shimohigashi, Y.; Sakaguchi, K. Characterization of the active site and a unique uncompetitive inhibitor of the PPM1-type protein phosphatase PPM1D. Protein Pept. Lett. 2008, 15, 938-948. [CrossRef] [PubMed]

14. Pan, C.; Tang, J.; Xu, Y.; Xiao, P.; Liu, H.; Wang, H.; Wang, W.; Meng, F.; Yu, X.; Sun, J. The catalytic role of the M2 metal ion in PP2C $\alpha$. Sci. Rep. 2015, 5, 8560. [CrossRef]

15. Cohen, P.T. Novel protein serine/threonine phosphatases: Variety is the spice of life. Trends Biochem. Sci. 1997, 22, 245-251. [CrossRef]

16. Zhang, Y.; Kim, Y.; Genoud, N.; Gao, J.; Kelly, J.W.; Pfaff, S.L.; Gill, G.N.; Dixon, J.E.; Noel, J.P. Determinants for dephosphorylation of the RNA polymerase II C-terminal domain by Scp1. Mol. Cell 2006, 24, 759-770. [CrossRef]

17. Allen, K.N.; Dunaway-Mariano, D. Phosphoryl group transfer: Evolution of a catalytic scaffold. Trends Biochem. Sci. 2004, 29, 495-503. [CrossRef]

18. Jeronimo, C.; Collin, P.; Robert, F. The RNA Polymerase II CTD: The Increasing Complexity of a Low-Complexity Protein Domain. J. Mol. Biol. 2016, 428, 2607-2622. [CrossRef]

19. Harlen, K.M.; Churchman, L.S. The code and beyond: Transcription regulation by the RNA polymerase II carboxy-terminal domain. Nat. Rev. Mol. Cell Biol. 2017, 18, 263-273. [CrossRef]

20. Wang, W.; Liao, P.; Shen, M.; Chen, T.; Chen, Y.; Li, Y.; Lin, X.; Ge, X.; Wang, P. SCP1 regulates c-Myc stability and functions through dephosphorylating c-Myc Ser62. Oncogene 2016, 35, 491-500. [CrossRef]

21. Sun, T.; Fu, J.; Shen, T.; Lin, X.; Liao, L.; Feng, X.; Xu, J. The Small C-terminal Domain Phosphatase 1 Inhibits Cancer Cell Migration and Invasion by Dephosphorylating Ser(P)68-Twist1 to Accelerate Twist1 Protein Degradation. J. Biol. Chem. 2016, 291, 11518-11528. [CrossRef] [PubMed]

22. Lin, Y.; Lu, L.; Chen, H.; Duan, X.; Lin, X.; Feng, X.; Tang, M.; Chen, R. SCP phosphatases suppress renal cell carcinoma by stabilizing PML and inhibiting mTOR/HIF signaling. Cancer Res. 2014, 74, 6935-6946. [CrossRef]

23. Tang, M.; Lu, L.; Huang, Z.; Chen, L. Palmitoylation signaling: A novel mechanism of mitochondria dynamics and diverse pathologies. Acta Biochim. Biophys. Sin. 2018, 50, 831-833. [CrossRef] [PubMed]

24. Krasnov, G.S.; Puzanov, G.A.; Afanasyeva, M.A.; Dashinimaev, E.B.; Vishnyakova, K.S.; Beniaminov, A.D.; Adzhubei, A.A.; Kondratieva, T.T.; Yegorov, Y.E.; Senchenko, V.N. Tumor suppressor properties of the small C-terminal domain phosphatases in non-small cell lung cancer. Biosci. Rep. 2019, 39, BSR20193094. [CrossRef]

25. Liao, P.; Wang, W.; Li, Y.; Wang, R.; Jin, J.; Pang, W.; Chen, Y.; Shen, M.; Wang, X.; Jiang, D.; et al. Palmitoylated SCP1 is targeted to the plasma membrane and negatively regulates angiogenesis. Elife 2017, 6, e22058. [CrossRef] [PubMed]

26. Sapkota, G.; Knockaert, M.; Alarcón, C.; Montalvo, E.; Brivanlou, A.H.; Massagué, J. Dephosphorylation of the linker regions of Smad1 and Smad2/3 by small C-terminal domain phosphatases has distinct outcomes for bone morphogenetic protein and transforming growth factor-beta pathways. J. Biol. Chem. 2006, 281, 40412-40419. [CrossRef] [PubMed] 
27. Wu, Y.; Evers, B.M.; Zhou, B.P. Small C-terminal domain phosphatase enhances snail activity through dephosphorylation. J. Biol. Chem. 2009, 284, 640-648. [CrossRef]

28. Sun, A.; Wang, M.; Li, B.; Meng, F. Down-regulation of miR-124 target protein SCP-1 inhibits neuroglioma cell migration. Eur. Rev. Med. Pharmacol. Sci. 2017, 21, 723-729.

29. Rallabandi, H.R.; Ganesan, P.; Kim, Y.J. Targeting the C-Terminal Domain Small Phosphatase 1. Life (Basel) 2020, 10, 57. [CrossRef]

30. Zhang, M.; Cho, E.J.; Burstein, G.; Siegel, D.; Zhang, Y. Selective inactivation of a human neuronal silencing phosphatase by a small molecule inhibitor. ACS Chem. Biol. 2011, 6, 511-519. [CrossRef]

31. Nozaka, A.; Nishiwaki, A.; Nagashima, Y.; Endo, S.; Kuroki, M.; Nakajima, M.; Narukawa, M.; Kamisuki, S.; Arazoe, T.; Taguchi, H.; et al. Chloramphenicol inhibits eukaryotic Ser/Thr phosphatase and infection-specific cell differentiation in the rice blast fungus. Sci. Rep. 2019, 9, 9283. [CrossRef] [PubMed]

32. Ishizaki, T.; Horai, Y. Review article: Cytochrome P450 and the metabolism of proton pump inhibitors-emphasis on rabeprazole. Aliment. Pharmacol. Ther. 1999, 13 (Suppl. 3), 27-36. [CrossRef] [PubMed]

33. Park, H.; Lee, H.S.; Ku, B.; Lee, S.R.; Kim, S.J. Two-track virtual screening approach to identify both competitive and allosteric inhibitors of human small C-terminal domain phosphatase 1. J. Comput. Aided. Mol. Des. 2017, 31, 743-753. [CrossRef] [PubMed]

34. Nimmo, G.A.; Cohen, P. The regulation of glycogen metabolism. Phosphorylation of inhibitor-1 from rabbit skeletal muscle, and its interaction with protein phosphatases-III and -II. Eur. J. Biochem. 1978, 87, 353-365. [CrossRef] [PubMed]

35. Foulkes, J.G.; Cohen, P. The regulation of glycogen metabolism. Purification and properties of protein phosphatase inhibitor-2 from rabbit skeletal muscle. Eur. J. Biochem. 1980, 105, 195-203. [CrossRef] [PubMed]

36. Eto, M.; Senba, S.; Morita, F.; Yazawa, M. Molecular cloning of a novel phosphorylation-dependent inhibitory protein of protein phosphatase-1 (CPI17) in smooth muscle: Its specific localization in smooth muscle. FEBS Lett. 1997, 410, 356-360. [CrossRef]

37. Li, M.; Satinover, D.L.; Brautigan, D.L. Phosphorylation and functions of inhibitor-2 family of proteins. Biochemistry 2007, 46, 2380-2389. [CrossRef]

38. Flint, A.J.; Tiganis, T.; Barford, D.; Tonks, N.K. Development of "substrate-trapping" mutants to identify physiological substrates of protein tyrosine phosphatases. Proc. Natl. Acad. Sci. USA 1997, 94, 1680-1685. [CrossRef]

39. Nunes-Xavier, C.E.; Martín-Pérez, J.; Elson, A.; Pulido, R. Protein tyrosine phosphatases as novel targets in breast cancer therapy. Biochim. Biophys. Acta 2013, 1836, 211-226. [CrossRef]

40. Boubekeur, S.; Boute, N.; Pagesy, P.; Zilberfarb, V.; Christeff, N.; Issad, T. A new highly efficient substrate-trapping mutant of protein tyrosine phosphatase 1B (PTP1B) reveals full autoactivation of the insulin receptor precursor. J. Biol. Chem. 2011, 286, 19373-19380. [CrossRef]

41. Barford, D. Molecular mechanisms of the protein serine/threonine phosphatases. Trends Biochem. Sci. 1996, 21, 407-412. [CrossRef]

42. Wu, D.; De Wever, V.; Derua, R.; Winkler, C.; Beullens, M.; Van Eynde, A.; Bollen, M. A substrate-trapping strategy for protein phosphatase PP1 holoenzymes using hypoactive subunit fusions. J. Biol. Chem. 2018, 293, 15152-15162. [CrossRef] [PubMed]

43. Otsubo, K.; Yoneda, T.; Kaneko, A.; Yagi, S.; Furukawa, K.; Chuman, Y. Development of a Substrate Identification Method for Human Scp1 Phosphatase Using Phosphorylation Mimic Phage Display. Protein Pept. Lett. 2018, 25, 76-83. [CrossRef] [PubMed]

44. Yoshida, T.; Yamazaki, K.; Imai, S.; Banno, A.; Kaneko, A.; Furukawa, K.; Chuman, Y. Identification of a Specific Inhibitor of Human Scp1 Phosphatase Using the Phosphorylation Mimic Phage Display Method. Catalysts 2019, 9, 842. [CrossRef]

45. Nesti, E.; Corson, G.M.; McCleskey, M.; Oyer, J.A.; Mandel, G. C-terminal domain small phosphatase 1 and MAP kinase reciprocally control REST stability and neuronal differentiation. Proc. Natl. Acad. Sci. USA 2014, 111, 3929-3936. [CrossRef]

46. Kim, Y.J.; Bahk, Y.Y. A study of substrate specificity for a CTD phosphatase, SCP1, by proteomic screening of binding partners. Biochem. Biophys. Res. Commun. 2014, 448, 189-194. [CrossRef] 
47. Knockaert, M.; Sapkota, G.; Alarcón, C.; Massagué, J.; Brivanlou, A.H. Unique players in the BMP pathway: Small C-terminal domain phosphatases dephosphorylate Smad1 to attenuate BMP signaling. Proc. Natl. Acad. Sci. USA 2006, 103, 11940-11945. [CrossRef]

48. Yeo, M.; Lee, S.K.; Lee, B.; Ruiz, E.C.; Pfaff, S.L.; Gill, G.N. Small CTD phosphatases function in silencing neuronal gene expression. Science 2005, 307, 596-600. [CrossRef]

49. Burkholder, N.T.; Mayfield, J.E.; Yu, X.; Irani, S.; Arce, D.K.; Jiang, F.; Matthews, W.L.; Xue, Y.; Zhang, Y.J. Phosphatase activity of small C-terminal domain phosphatase 1 (SCP1) controls the stability of the key neuronal regulator RE1-silencing transcription factor (REST). J. Biol. Chem. 2018, 293, 16851-16861. [CrossRef]

50. Ayad, N.G.; Rankin, S.; Murakami, M.; Jebanathirajah, J.; Gygi, S.; Kirschner, M.W. Tome-1, a trigger of mitotic entry, is degraded during G1 via the APC. Cell 2003, 113, 101-113. [CrossRef]

51. Kamenski, T.; Heilmeier, S.; Meinhart, A.; Cramer, P. Structure and mechanism of RNA polymerase II CTD phosphatases. Mol. Cell 2004, 15, 399-407. [CrossRef] [PubMed]

52. Cho, H.; Wang, W.; Kim, R.; Yokota, H.; Damo, S.; Kim, S.H.; Wemmer, D.; Kustu, S.; Yan, D. BeF(3)(-) acts as a phosphate analog in proteins phosphorylated on aspartate: Structure of a $\operatorname{BeF}(3)(-)$ complex with phosphoserine phosphatase. Proc. Natl. Acad. Sci. USA 2001, 98, 8525-8530. [CrossRef]

53. Ghosh, A.; Shuman, S.; Lima, C.D. The structure of Fcp1, an essential RNA polymerase II CTD phosphatase. Mol. Cell 2008, 32, 478-490. [CrossRef] [PubMed]

54. Schwer, B.; Ghosh, A.; Sanchez, A.M.; Lima, C.D.; Shuman, S. Genetic and structural analysis of the essential fission yeast RNA polymerase II CTD phosphatase Fcp1. RNA 2015, 21, 1135-1146. [CrossRef] [PubMed]

55. Fedorov, A.; Shi, W.; Kicska, G.; Fedorov, E.; Tyler, P.C.; Furneaux, R.H.; Hanson, J.C.; Gainsford, G.J.; Larese, J.Z.; Schramm, V.L.; et al. Transition state structure of purine nucleoside phosphorylase and principles of atomic motion in enzymatic catalysis. Biochemistry 2001, 40, 853-860. [CrossRef]

56. Schramm, V.L. Enzymatic Transition States and Drug Design. Chem. Rev. 2018, 118, 11194-11258. [CrossRef]

57. Weiss, E.R.; Göttlinger, H. The role of cellular factors in promoting HIV budding. J. Mol. Biol. 2011, 410, 525-533. [CrossRef]

58. Bouamr, F.; Houck-Loomis, B.R.; Santos, M.D.L.; Casaday, R.J.; Johnson, M.C.; Goff, S.P. The C-terminal portion of the Hrs protein interacts with Tsg101 and interferes with human immunodeficiency virus type 1 Gag particle production. J. Virol. 2007, 81, 2909-2922. [CrossRef]

59. Elliott, A.M.; Simard, L.R.; Coghlan, G.; Chudley, A.E.; Chodirker, B.N.; Greenberg, C.R.; Burch, T.; Ly, V.; Hatch, G.M.; Zelinski, T. A novel mutation in KIAA0196: Identification of a gene involved in Ritscher-Schinzel/3C syndrome in a First Nations cohort. J. Med. Genet. 2013, 50, 819-822. [CrossRef]

60. Van Beuningen, S.F.B.; Will, L.; Harterink, M.; Chazeau, A.; van Battum, E.Y.; Frias, C.P.; Franker, M.A.M.; Katrukha, E.A.; Stucchi, R.; Vocking, K.; et al. TRIM46 Controls Neuronal Polarity and Axon Specification by Driving the Formation of Parallel Microtubule Arrays. Neuron 2015, 88, 1208-1226. [CrossRef]

61. Yan, D.; Cho, H.S.; Hastings, C.A.; Igo, M.M.; Lee, S.Y.; Pelton, J.G.; Stewart, V.; Wemmer, D.E.; Kustu, S. Beryllofluoride mimics phosphorylation of $\mathrm{NtrC}$ and other bacterial response regulators. Proc. Natl. Acad. Sci. USA 1999, 96, 14789-14794. [CrossRef] [PubMed]

Publisher's Note: MDPI stays neutral with regard to jurisdictional claims in published maps and institutional affiliations.

(C) 2020 by the authors. Licensee MDPI, Basel, Switzerland. This article is an open access article distributed under the terms and conditions of the Creative Commons Attribution (CC BY) license (http://creativecommons.org/licenses/by/4.0/). 